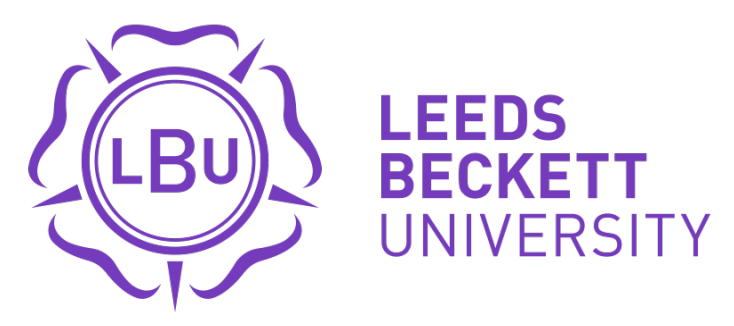

Citation:

Florian, L and Beaton, MC (2018) Inclusive pedagogy in action: getting it right for every child. International Journal of Inclusive Education, 22 (8). pp. 870-884. ISSN 1360-3116 DOI: https://doi.org/10.1080/13603116.2017.1412513

Link to Leeds Beckett Repository record:

https://eprints.leedsbeckett.ac.uk/id/eprint/4799/

Document Version:

Article (Accepted Version)

This is an Accepted Manuscript of an article published by Taylor \& Francis in International Journal of Inclusive Education on 12 December 2017, available online: http://www.tandfonline.com/10.1080/13603116.2017.1412513

The aim of the Leeds Beckett Repository is to provide open access to our research, as required by funder policies and permitted by publishers and copyright law.

The Leeds Beckett repository holds a wide range of publications, each of which has been checked for copyright and the relevant embargo period has been applied by the Research Services team.

We operate on a standard take-down policy. If you are the author or publisher of an output and you would like it removed from the repository, please contact us and we will investigate on a case-by-case basis.

Each thesis in the repository has been cleared where necessary by the author for third party copyright. If you would like a thesis to be removed from the repository or believe there is an issue with copyright, please contact us on openaccess@leedsbeckett.ac.uk and we will investigate on a case-by-case basis. 
Florian, L \& Beaton, M (in press): Inclusive pedagogy in action: getting it right for every child, International Journal of Inclusive Education

\title{
Inclusive pedagogy in action: Getting it right for every child
}

\author{
Lani Florian and Mhairi Beaton
}

\section{Introduction}

Inclusive pedagogy, also referred to as the inclusive pedagogical approach, is a pedagogical response to individual differences between pupils that avoids the marginalisation that can occur with differentiation strategies that are designed only with individual needs in mind. These problems include the 'repetition of exclusion' (Allan, 2006; Slee, 2010) whereby learners are included in the classroom but excluded from opportunities to participate in collaborative or group activities because the work they are given is differentiated to such an extent that they end up isolated from the classroom community even though they may be physically present. The inclusive pedagogical approach was developed in response to questions about how individual pupils can receive the additional support or extra help they need without treating them differently from others (Florian \& Black-Hawkins, 2011).

Although this innovative approach begins with an acknowledgement that the process of providing for all pupils by differentiating for some on the basis of individual need can be problematic when it calls attention to differences between learners (Florian, 2015), individualisation is a common educational practice. Black and Wiliam's seminal review of teaching practice (1998) identified learning goals (either constructed with pupils or clearly articulated to them), questioning practices, teacher feedback and the use of peer and self-assessment as significant classroom practices leading to enhanced teaching, learning and assessment for both teachers and pupils. Although Black and Wiliam suggested that these practices would benefit all pupils, especially those most at risk of school failure, our studies of teachers' inclusive practice have clarified that marginalisation for some pupils within classroom activity does not necessarily occur because of the teachers' choice of strategy but the way in which it is enacted (e.g. (e.g. Florian, 2015; Florian and Black-Hawkins, 2011;Florian, Black-Hawkins, and Rouse, 2017). To help us understand this process, we assume that a single lesson is a different experience for each participant in it, and our focus is on the ways that teachers ensure that everyone has the opportunity for meaningful engagement in the lesson.

The case presented in this paper is drawn from a larger exploratory study designed to examine the role of pupil voice in self-assessment and in teachers' formative assessments of learning. We chose the concepts of pupil voice and self-assessment because of their relevance to the implementation of policy initiatives aimed to enhance student achievement that call for greater involvement of learners in the assessment process such as Assessment for Learning (AfL in England) and Assessment is for Learning (AifL in Scotland). These wider polices are consistent with our current articulation of inclusive pedagogy which includes AfL practices (Florian, 2015).

\section{The role of pupil voice in self-assessment and teachers' formative assessments}


Self-assessment is defined as the process whereby children assess their own learning, including how they make decisions about the level of difficulty of the work they can do, and what work samples represent their best work. It has been described as an essential component of formative assessment (Black \& Wiliam, 1998:143) that assumes people learn in an interactive way (Sadler, 1989). Through self-assessment, pupils are included as agents of assessment rather than objects to be assessed (Black \&William, 2009).

Self-assessment provides pupils with opportunities to develop a clear sense of their progress as they compare their current work to previous work, rather than only to the achievements of others. This is important because as Boud (1995) explains, selfassessment can be an emancipatory practice for pupils subjected to ability grouping practices where they learn how others judge them. Self-assessment provides pupils with opportunities to recognize that they have responsibilities in the learning process counter to what Gunter and Thomson (2007) refer to as the burden of 'elite adult plans'. An understanding of self-assessment as an important aspect of formative assessment embraces the view that pupils themselves are able to offer accurate descriptions of their abilities and that through self-assessment, their thinking about where next to take their learning is enhanced.

Yet, Falchikov's (2005) review of the literature on formative assessment found that learner control in self-assessment varies greatly. While self-assessment is promoted as good practice in classrooms, its use 'has grown at a more rapid rate than the dissemination of good practice' (Boud, 1995, p.23). While Boud provided examples of self-assessment strategies that limited rather than enhanced pupil responsibility for learning, Bourke \& Mentis (2014) showed how self-assessment empowers both learners and teachers. These ostensibly contradictory findings reinforce our view that close attention must be paid not only to the choice of using a pedagogical strategy but the way in which it is enacted.

A key challenge for many teachers is not simply learning to listen to pupils but using what they have learned from listening to inform future practice. Black and Wiliam (1998) note that for,

"pupils to communicate their evolving understanding......Discussion, observation of activities, marking of written work, can all be used to provide the opportunities, but it is then important to look at, or listen carefully to, the talk, the writing, the actions through which pupils develop and display the state of their understanding." (1998, p.10-11)

Clearly pupils have important things to say about their abilities and their learning. But how do teachers access this information, how do they listen, and how do they use what they are hearing to improve teaching and learning? These are big questions not easily studied or answered. However, detailed studies of teachers' practice can provide helpful insights about some of the more elusive processes of teaching and learning. Hintz and Tyson (2015) used interaction analysis to study how teachers and pupils co-construct knowledge in mathematics lesson. Through fine grained analyses of lesson fragments, they found that listening is complex and dynamic work whereby teachers actively support multiple forms of pupil listening during lessons that have implications for what pupils learn. As English (2011) notes: "listening is not a one-sided passive aspect of learning. Rather it implies an interrelation between people, in which each is open to the other ( $\mathrm{p}$. 172).

\section{Research design and process}


The study was designed to extend our work on the concept of inclusive pedagogy, which had highlighted the importance of the teacher-learner relationship. The aim was to work collaboratively with teachers and pupils to deepen our sociocultural understanding of inclusive pedagogy by focusing on the teacher-learner relationship rather than the teacher and school practices that had been the focus of analysis in our previous studies. In discussions with the teachers who were to become our research partners, we chose to explore a refinement of a question asked by many teachers but articulated by one of our colleagues as: how do I know I got it right for every child? This important question led us to consider assessment practices in general, and over time our study focus was further refined to focus how pupil voice as an aspect of self-assessment, itself a formative assessment practice, might be used to improve learning.

For the purpose of the study, we considered self-assessment, a divergent practice that reflects a view of learning as a social as well as cognitive process. Consistent with Pryor and Crossouard's (2008) typology of convergent and divergent formative assessment practices (outlined in Table 1), divergent assessment practices are interactive and iterative, whereas convergent assessment practices are based on a view of knowledge as a body of facts that can be transmitted and acquired.

\section{INSERT TABLE 1 ABOUT HERE}

Pryor and Crossouard (2008) note that it is difficult to engage in divergent assessment practices in today's educational climate because of its heavy reliance on standardised assessment as an accountability measure, a finding also reported by Hayward, Priestley and Young (2004). Taking account of the complex environment in which teaching practice occurs as well as the subjective nature of our inquiry necessitated a methodological stance and method of collecting data that would enable us to document divergent assessment practices as they occurred.

Consistent with our previous studies, we followed McIntyre's (2009) argument that experienced teachers hold a 'craft knowledge' that should be privileged in research about teaching and learning. As a methodological stance, craft knowledge focuses on the practical wisdom of teachers. It focuses on successful practice and how teachers make sense of things. Most importantly it assumes teachers are competent rather than deficient or lacking in skills that need to be developed. In agreeing to explore the 'getting it right' question asked by teachers, we were interested in what we could learn from working with them to articulate their craft knowledge about it as they sought to understand how listening to pupil voices as an aspect of their self-assessment of learning might be used to enhance it.

The craft knowledge stance provided a methodological starting point for the researchers that guided a collaborative project over the course of an academic year working alongside three classroom teachers in two schools for approximately twelve hours each week. Two of the three classrooms were reception classes comprised of 30 pupils (ages 4-5) each and 24 pupils were enrolled in a primary classroom (ages 7-8). Three participant researchers, one in each classroom where the data were collected, and three class teachers worked collaboratively with their pupils to identify and capture key 'learning moments', described by Coyle and her colleagues (2010) as experiences identified by teachers and pupils that describe events they consider important. Learning moments selected and video recorded by the pupils and teachers were uploaded to a digital repository, LOCIT (Lesson Observation and Critical Incident Technique), a data storage tool (Coyle et al., 2010) 
specifically designed to enable practice-based evidence of 'learning moments' identified by teachers and pupils to be collected for analysis. It permits teachers and pupils to gather their own evidence of what they believe to be important. In this way, the process is nonjudgemental and owned by those using it. As an online storage tool, it facilitates and structures the process of collecting, editing and commenting on chosen examples of classroom practice or interaction - photographic, video, audio and text - so that examples may be scrutinised as part of a conversation relevant to the professional learning or research project of interest. Importantly, it enables an accompanying narrative space for teachers and pupils to reflect on learning moments and determining for themselves what constitutes good practice. (Coyle, 2011, p.1).

Our data set comprised field notes, video footage, semi-structured interviews with pupils about their learning, shared reflections between teachers and researchers posted on a google site and recorded discussions between teachers, pupils and researchers. Recorded discussions were those that occurred between teachers, pupils and researchers as they reviewed the video footage of learning moments recorded on LOCIT. While static cameras were used to capture some interactions, the hand-held digital cameras were essential in enabling pupils and teachers to determine and record examples that they felt captured important 'learning moments'. Although now obsolete, we used FLIP cameras with a built-in USB connection to record events that could be later reviewed with children. However, today any wireless camera that can be worn on a lanyard would enable adults or children to easily record and immediately review their 'learning moments'

Over a period of two years, the field researchers, teachers, project director and an external evaluator, appointed to serve as a critical friend to the project participated in regularly scheduled team meetings and seminars. The meetings enabled ongoing data analysis through a continuous collaborative process of reviewing selected video and accompanying narratives that the team agreed exemplified examples of listening to pupils reflect on their learning. These exemplars were interrogated by the research team for insights about how the teachers were determining if they were 'getting the learning right for every child'. This ongoing collaborative process of data collection and analysis was designed to enable theoretical developments about inclusive pedagogy to form part of the study findings. Although the pupils did not participate in the meetings and seminars, they were considered partners in the research. In each of the three classroom sites they collaborated with teachers and researchers to collect data during the project by capturing video footage and recording stories of their learning, and worked with adults to help clarify the ideas that emerged from the data.

As the number of videos in the repository increased, pupils and teachers began to make decisions about the relevance of each video clip, retaining and deleting them to suit their own purposes. For example, teachers tended to retain clips that served as evidence of the pupils' progress as active learners for school recording and reporting purposes whereas pupils chose to retain clips that evidenced moments where they reported feeling proud or happy about their learning. As this was an ongoing process where video clips were constantly collected, retained or deleted by many different participants, the research team did not maintain a count of the number of recordings or attempt an analytic approach that would require that every video clip be considered data. Instead, the researchers wrote weekly reflective accounts following their review of what had been collected on a shared google site and was available to the whole team for analysis. 
The LOCIT process proved useful to our ongoing analysis in three significant ways. Firstly, in each of the sites, the recording of classroom activity and the children's responses to their learning formed a basis for pupil/teacher dialogue to take place in the classroom during or immediately after the activity. Once uploaded onto LOCIT, these recordings allowed the teachers to review their practice in dialogue with the researchers. Finally, the LOCIT site allowed both teachers and researchers to collaboratively analyse significant moments in practice despite the geographical distance that separated them.

\section{Findings}

Although data were collected and analysed across three sites, our findings were manifest in the practice of each teacher and are presented here as they are reflected in the practice of the primary class teacher. By isolating the findings from one site we aim to offer a clear example of how craft knowledge develops. In so doing, we take up Grumet's (2014) inducement to share stories about teaching as 'records of subjectivity, precious, unrepeatable, unforeseen' (p.25). The stories in our example are intended to illustrate how teachers can use what they learn from listening to pupils' self-assessments of their learning in ways that meet the standard of inclusive pedagogy.

We choose to focus on the primary class examples for two reasons. One is because the contextual differences between reception and primary classrooms are sufficiently different to warrant separate treatment. The second is because of all of the teachers involved in our study, Sally (a pseudonym) made the most significant changes to her practice and therefore the shift in her thinking is well-defined for the purpose of illustrating how craft knowledge can inform further theorising about inclusive pedagogy. Sally had entered the teaching profession late in life following a successful career in the field of science. The decision to change career was based on a deeply held conviction that through dedication and hard work as a classroom teacher, she could successfully guide her pupils' learning in ways that would enhance their life chances. Now in her sixth year of teaching, she was eager to embrace new ways of working that might assist with this endeavour.

In this case, our analysis of 200 hours of data captured by the static camera which was running continuously during the time the researcher was in the classroom was supplemented by approximately 20 hours of footage recorded by the teachers and pupils in short sequences throughout the year to record their 'learning moments'. In addition, individual semi-structured interviews were conducted with each of the pupils $(n=24)$ in the primary classroom focusing on their understanding of the definition of learning and their individual understanding of their developing learner identity within the classroom. These interviews were transcribed and thematically analysed. The initial themes were identified as:

- surprise

- progress/progression

- respect/trust

- dialogue/sharing/discussion/response

- co-agency/collaboration

- professional tension

These themes were elaborated with descriptions of activities and occurrences within the classroom from both field notes and from the video footage captured throughout the year. Further thematic analysis of the commentary recorded by teachers using the LOCIT 
system allowed the researchers access to the rationale that the teachers (in this case, Sally) were expressing in relation to decisions they made about their classroom practice. Finally, narrative stories describing particular episodes which related to the emergent themes, often from the point of view of one of the pupils to whom it had been most significant, were developed as a way of collecting 'learning moments' for analysis and presentation to the wider research team.

As we embarked on data analysis, concurrent doctoral research undertaken by a member of the research team (Beaton, 2015) made us aware that although many of the pedagogic strategies linked to formative assessment were evident in practice, teachers retained control of them. Although pupils articulated support for their teachers and understood why teachers made particular decisions, they also expressed frustration that they were not partners in the learning process. Their voices were heard but control of what was discussed remained with the teacher. In addition to Askew and Lodge's suggestion of a mis-match between theory and practice in assessment (2000), Beaton suggests that the teachers' control of these formative assessment processes is linked to their professional identity as classroom teachers with responsibility for the teaching, learning and assessment in their classrooms. Retaining responsibility for successful learning was fundamental to their identity as successful classroom teachers despite expressions of the importance of listening to pupils' voices. The teachers retained a deep-seated traditional understanding of the nature of childhood that undermined a belief in the competence of the pupils to actively contribute to and understand their own learning. This, allied with the external pressures of accountability and their own implicit desire to maintain the integrity of their professional identity as successful classroom practitioners, resulted in their control of formative assessment practices. We were interested in mining the data to learn more about what might happen if or when teachers relinquished control.

Following Pryor and Crossouard's (2010) distinction between teachers who adopt 'convergent' assessment practices taking the role of teacher as assessor and those who position themselves as learners themselves, adopting more 'divergent' assessment practices (see Table 1), we were able to explore changes in Sally's practice as well as shifts in her thinking about practice and these are exemplified in a number of the narrative accounts below. Initially Sally's formative assessment practices were consistently convergent. Field notes and video footage in the early stages of the project demonstrate that Sally enacted formative assessment strategies primarily during the plenaries at the end of lessons. These sessions at the end of planned lessons were viewed by Sally as opportunities to assess the learning of the class against the learning intentions planned before the lesson - often linked to the curricular outcomes outlined in national and local policy documentation.

An example from early in the data collection phase of the project records Sally gathering the class together to conduct a plenary session following a maths lesson. Small whiteboards and erasable pens were distributed to all the pupils. Sally then proceeded to request that each pupil write the answer to a series of numeracy questions on the whiteboard linked to the previous lesson on multiplication. After each question was announced, the pupils were cued 'Show me!' and this prompted them to hold up the white boards to demonstrate their written answer to Sally. Sally would then move round the class indicating whether the answer was correct, or whether the individual pupil should check their answer again as it was incorrect. No discussion was conducted as to how the student's arrived at their answer, correct incorrect answers or to indicate that there might be more than one way to obtain a correct answer. The process was a 'tick box' exercise 
which allowed Sally to ascertain which pupils had achieved the learning outcomes specified at the beginning of the lesson; a convergent form of assessment.

Sally's assessment practices seemed to reflect a view of learning that was not always consistent with the socio-cultural perspective on learning she articulated when describing her approach to teaching and learning. The children worked frequently in collaborative groupings to complete open-ended tasks. However, at the end of lessons, Sally would adopt a convergent form of assessment by reviewing what had been accomplished and what the pupils could do. Consistent with other research on teachers' formative assessment practices that purport to involve self-assessment (e.g. Hargreaves, 2005; Pryor \& Crossouard, 2010), the pupils' self-assessment practices were based on the tick list approach and were controlled firmly by Sally.

However, the use of the FLIP cameras to record data and the analysis process facilitated through LOCIT allowed Sally to rethink how she understood her practice. At the beginning of the data collection period, the cameras were used at the end of lessons because that was where the formative assessment was thought to occur. However, it soon became apparent that in selecting a whole class activity as a learning moment, only certain children had the opportunity to speak. Over time Sally began to speak about how surprised she was by the knowledge and understanding the pupils were able to express, leading her to trust the pupils more fully as learners and express respect for their learning. As Sally began to make use of this information that the children gave her, she began to carry the FLIP camera around with her and spontaneously interview the children either individually or in a group during the activities. Although this remained a teacher directed activity, the camera allowed the pupils to be more aware of the fact that Sally was listening to them and could make connections to the changes in the classroom practices which resulted from their comments and suggestions. The analysis of the field notes, video footage and Sally's own commentary on the video showed that she began to conduct the formative self-assessment process within the class in a divergent manner reflecting 'a more open engagement with what the student can do, addressing the learner's agenda with a 'more dialogic, conversational form of language' (Pryor \& Crossouard, 2010, p. 272).

Over time, Sally began to ask more open-ended questions during the lesson plenaries. During late January, the class had spent most of the morning engaged in maths activities related to time. Video footage of the plenary session following these activities shows how the pupils had been practising time including 'o'clock' and half past' using small plastic clocks. During the plenary session Sally asks the question 'What was your learning today?' thereby opening up the possibility for pupils to articulate the learning which occurred and which was significant for them as individuals. Sally then opened the dialogue further with the question: 'Is there anything else you would like to share about your learning?' Immediately, Ben, put up his hand and commented:

'The thing is I really think I have got all this maths. I really got it last time so I don't need to do it again this week. Can we not do more advanced maths - like 24-hour clock? I'd really like to do that sort of thing.'

For a pupil to question a teacher's lesson in this way could easily have been considered a challenge to the professional knowledge and authority of the teacher and many interpretations of Ben's question arise. For some this may have been dismissed as too challenging for the class because the 24-hour clock is generally taught the following year. 
However, the video footage then records that another pupil, Michael, a pupil identified as having special needs raised his hand and said:

\section{'I'd like to learn about the minutes past and to'}

Rather than acting on judgements of Michael and Ben as respectively immature, advanced or lacking in the ability to self-assess their own progress accurately, Sally took some time to consider the request and then explained that she believed that Michael had made an accurate assessment of his next steps in maths and that there would be an activity in the lesson later that day which would address his request. Later when reviewing the video footage Sally commented:

'I embrace all feedback on two levels. Firstly, to inform my planning and to informally assess where they are at with their learning. Secondly I evaluate my own teaching and thus learn to improve and bring these reflections to more meaningful learning.'

Sally chose to listen attentively to these comments and allow the class, after break-time, to opt to engage with more challenging maths rather than the activities originally planned. Immediately after the interval, she introduced the options of activities related to 'minutes past and minutes to the hour' and related to the 24-hour clock. The activities were structured so that all the children in the class had the option of joining the activity they believed was appropriate for their own learning. As Ben commented:

'So, it is pretty good now. We get to choose exactly what level of maths we do. Sometimes I choose a really hard one and even if I get stuck, well I can try a different one and come back to it.'

Sally acknowledged this event as an important 'learning moment' in her own practice. As she commented:

'Listening to the children has made me more aware of what they can actually manage. Some of them have really surprised me. You know... what they can actually achieve. I'd never have given them work like that but they seem to know that they can manage it and so the work level has really lifted as they have embraced the responsibility.'

As Sally became more confident in listening to the pupils and making decisions based on their dialogue, it became apparent that pupils were not only contributing to curricular decisions but also to pedagogic decisions. Following an activity she learned from another teacher involved in the research, Sally initiated what she called 'The Big Conversation'. This involved weekly discussions with the pupils to review the learning that had occurred during the week and discuss collaborative plans for future learning. In introducing this, Sally signalled to the pupils that the discussion would be a two-way conversation, not led wholly by the adults. She began the first 'Big Conversation' with an invitation for their help with the request:

'I need you to help me. I'd like to know what helps you do your best learning in class? The important and the little things, as well?'

One of the pupils, Mary, spoke about how it would be more meaningful if maths was realistic:

'I think we should have a shop. It would be a shop in the classroom and we could make things to sell in it and practise our money exchanges.' 
The class indicated an enthusiastic response to this suggestion. Subsequently, Sally and the class made the decision that their maths work would focus on the setting up and operation of the shop for the next few weeks. In reality it became a class project involving a number of curricular areas beyond maths - art, drama, citizenship, language, social subjects - and became a real focus for interdisciplinary learning. All decisions were made by the class during the 'Big Conversation' and although at times some of the pupils (and Sally) found this democratic process challenging, the activity aligned with Sally's desire to achieve greater 'relevance' in her teaching in line with government and local policy.

Finally, the observational data from the project also documented times when individuals were attempting to articulate their views of their learning but for a variety of reasons the teachers were not hearing them. An example in Sally's class involved a boy with a reputation for being mischievous. Simon was an articulate member of the class but often seemed to be disengaged with the activities on offer. He was captured on video during a maths lesson playing with a marble at his desk. Sally was quick to spot he was not completing his activity and reprimanded him. The pupil initially hid the marble in his pocket but as soon as Sally moved to another group, he took the marble out again and resumed the rolling game on the table top. Subsequent to the lesson, the participant researcher offered Simon the opportunity to view the video of his activities with the marble and jokingly pointed out that he had been caught 'mucking about'. Simon indignantly defended his actions. He explained that he already understood the maths the class were engaged with and therefore did not believe he should be required to engage in the officially sanctioned activities. Having not been given the opportunity to voice his previous learning, he had used his actions to indicate to the teacher, albeit unsuccessfully, that he did not believe that he needed this lesson.

Nevertheless, Sally continued to articulate a wish to be able to hear her pupils better. Early in the project she had expressed concern that she was not getting to know the four youngest girls in the class. During the course of the year, one of the girls, Mary, had found her voice as evidenced by her willingness to ask for maths to be more realistic. While this was a matter of profound professional satisfaction for Sally, she continued to express concern that she had not "found the key to unlocking the voices of the other three girls in the group". Sally believed that the key lay in the manner in which she asked questions of the pupils. As the year progressed, she trialled a number of increasingly open-ended ways of asking the pupils to self-assess their learning hoping that she might find the 'key to unlock all their voices'. She also worried that the classroom was being dominated by a group of older, boisterous boys making it more challenging to hear the voices of the three younger, quieter girls. However, even with the boys, Sally was aware that underneath 'their veneer of confidence there was an element of uncertainty', which she believed they were not ready to share with her. Sally's disappointment that she had not found the key to hearing/listening to all the pupils echoed concerns expressed by the other two teachers that, by not effectively hearing the voices of all the pupils, they were not sure if they were doing the best for them.

Interestingly, the use of LOCIT which was initially intended to be a repository for 'learning moments', quickly became a teaching and analysis tool. Using LOCIT to record and reflect on her lessons and interactions with pupils enabled Sally to develop divergent assessment practices and encouraged her to take up the role of teacher as learner rather than assessor. In conversations with the researcher she expressed appreciation for the opportunity to review the footage of the learning moments taking place in her classroom and consider with the researcher how her practice might be improved. She spoke of a 
sense of loss that the project would end, indicating that of the most important aspects of the project for was the opportunity to host the researcher in her classroom.

Sally also spoke of her concern that the responses of her colleagues to her new practices; in particular the move from convergent to divergent assessment practices might not be supported. At a time when the school was under pressure to raise standards, she was concerned that her school management team and other staff might not understand her reasons for the change in practice and be anxious that the class might progress more slowly through the curriculum. However, the collaborative review of the footage and the evidence this provided of the success of the change in practice gave Sally confidence that involving the pupils in self-assessment through divergent practices was leading to more successful learning. Indeed, when the researcher suggested an evening session sharing the project findings with the rest of the school staff, she was able to set aside her anxiety about presenting to colleagues, share the LOCIT footage of the pupils articulating their learning moments and explain how this process of reflection supported the development of her teaching practice.

\section{Discussion}

An unintended outcome of this study was our increasing awareness of how the data collection tool, LOCIT served a conduit for practice. Although the results presented here have focused on Sally, each of the three teachers participating in the project spoke about the progress that individual children had made as a result of measures they had put in place as a result of listening more carefully to them. While initially LOCIT was intended to a repository for 'learning moments', it quickly became a tool for practice-based evidence of learning outcomes. LOCIT enabled teachers to access many important things that pupils have to say about their abilities and learning that might otherwise have been overlooked. For example, as the unseen opportunity to hear Simon makes clear, the process of adopting divergent assessment practices is not a linear process. However, by using LOCIT to enhance her capacity to listen as well as to allow pupils to identify 'learning moments' that were important to them, Sally allowed her pupils to see that they were co-agent in the learning process.

Consistent with the craft knowledge stance adopted by the study, LOCIT focuses on positive practice - teachers and pupils choose the moments they want to be videoed and they choose what they thought was important for analysis. LOCIT also provides teachers and pupils with the means to reflect on empirical evidence of classroom practice, in this case about learner self-assessment. Although the teachers and pupils were free to determine what counted as a learning moment, the research team were particularly interested in 'learning moments' when pupils were active in self-assessment of their own learning and were willing to articulate this self-assessment either in verbal or other forms.

In actively involving learners in their own self-assessment Sally accepted that some of the learning objectives her pupils expressed might be different from those originally planned. Her willingness to engage with pupils on their own terms follows the tradition of child led learning exemplified by the Reggio Emilia philosophy that positions education as relationship (Malaguzzi, 1994) and views a pedagogy of listening is essential to learning (Rinaldi, 2001). In this study, pupils were able to identify 'learning moments' in different ways to adults; through their responses to activities, their suggestions for future learning and their actions. By taking their views seriously, Sally became co-agent with her pupils (Hart, et al, 2004), placing relationships 'at the heart of pedagogy' (Black and Wiliam, 
998 p. 16). As Sally sought to value the views of everybody, to accept that what was of value to the learners themselves, what was meaningful for them became part of learning for everybody. In this way, Sally was able to make learning meaningful for each individual pupil while avoiding the marginalisation that can occur when some pupils are treated differently to others. This is the hallmark of inclusive pedagogy.

An interesting insight into the teachers' thinking about the 'repetition of exclusion' (Allan, 2006; Slee, 2010) emerged in discussions with the teachers at the end of the project. All three teachers felt taking part in the project had enhanced their listening skills but they were also very clear that these skills were in need of being enhanced further. Research on assessment practices that focus on how learning occurs in relationship (Bourke, 2016) can support the development of a pedagogy of listening. Each of our teachers spoke of individuals or groups of pupils they felt they had not heard sufficiently. For Sally this was the group of girls whose voices she felt she had not unlocked. Yet Sally had begun to listen in new ways to the pupils in her class and the information she collected as a result of this listening was influencing how she planned the next steps in learning. This is no small achievement because as Whitelock, Faulkner and Miell (2008) have pointed out, it involves some risk. There were times when Sally expressed doubts as to whether she was doing 'the best' for her pupils by spending such significant time listening to them. Sally often articulated the tension she was experiencing in what she referred to as the 'priorities of learning' by which she meant the expectations of colleagues, her senior management team and parents as outlined in the policy documentation that determined what should be taught and how at different stages of primary school, and her growing awareness of the potential benefits of listening to and acting on the children's comments and requests.

A major aspect of the teacher's professional identity is control. Divergent assessment practices can leave a teacher feeling vulnerable. When Ben and Michael challenged Sally's choice of material and when Mary suggested a different way of learning, Sally could have felt her professional identity threatened. However, as she began to deepen her understanding of the learner as an active agent - a subject as well as an object of the learning process (Brookhart, 2004), she began to adopt a different identity for herself as a learner and really listen to what the pupils had to say about their learning. In this way Sally shifted her thinking about learning as acquisition to what Hart, Dixon, Drummond and McIntyre (2004) call transformability, the idea that learning is open ended and the capacity to learn can change based on what happens in the present.

In accepting that the pupils are able to articulate the learning that is important and relevant for them, Sally tacitly rejects the idea of knowledge as transmission and begins to view it as meaning making. In trusting that the pupils can articulate their understanding of their own learning, and by demonstrating to them that she not only listens but also values their views by being willing to change her plans, Sally adopts an inclusive pedagogical stance. By changing her plan, she accommodates an individual difference but does so in a way that is respectful of all pupils, enhancing rather than limiting their opportunities to participate in whole class lessons.

In adopting divergent modes of formative assessment Sally shows how she relinquished the role of expert. Perhaps most significantly, despite some pressure in managing the 'Big Conversation' Sally showed us how she was able to accept the participation of pupils in pedagogic decisions. By introducing the Big Conversation as a formative assessment activity, she was able to relinquish control, becoming co-agent with the pupils in the 
learning process. The Big Conversation allowed the pupils the space to express things that were important to them about their learning and Sally was able to demonstrate not only that she was listening but also that she was using what the pupils said to inform teaching.

\section{Conclusion}

Much of the research promoting pupil voice in formative assessment practice has focused more on how teachers are implementing assessment strategies than how pupils are experiencing them and there is some evidence that old assumptions about the nature of childhood, based on traditional beliefs of children as not fully competent still reverberate in teachers' thinking. Acknowledging this implicit assumption creates a space for teachers to explore how a genuine partnership between adults and pupils can facilitate learning (Bourke, 2017; Hargreaves 2012, 2013). As our study has attempted to show the genuine sharing of decision-making about learning can enhance participation but understanding how craft knowledge develops is painstaking work that involves a long and in-depth analysis of the complex practice of teaching. As Brown and MacIntyre (1992) have argued developing understanding through an articulation and theorisation of teachers' craft knowledge enhances the capacity to develop practice both for individual teachers and those who prepare them.

This study sought to build on Hargreaves' (op. cit.) insight that the enactment of formative assessment practices does not automatically result in the desired enhancement of learning and teaching. As Simon aptly illustrated, we found that pupils may reject these practices and their potential use to assist them in understanding of their current learning and inform next steps in learning if they sense that they are not legitimate partners in the learning process. Simply using these strategies does not automatically result in desirable outcomes. It is the way that they are implemented that matters.

As Sally's stories suggest, only once a collaborative understanding has been reached can genuine and authentic work be conducted. The pupils in our study unmistakably differentiated authentic formative assessment practices occurring in their classrooms from situations where they were not genuinely treated as legitimate partners in the assessment process. Clearly a focus on the reciprocal process - evidenced by the ways in which teachers demonstrate to children how they listen and use what they learn to direct their own teaching - enhances the formative assessment process.

To date our studies of inclusive pedagogy have focused on how teachers are able to include everyone without marginalising some. The focus in this study was on teacher and student assessment practice, and how teachers use what they learn from listening to pupils. This adds important new insights into the inclusive pedagogical approach. By responding to the individual needs of Ben and Michael in a way that not only demonstrated to each of them that she was listening because of how she acted on what she heard them say in her lessons, Sally was able to attend to their differences in ways that enhanced rather than inhibited learning. In this way, she met the standard of inclusive pedagogy which requires taking differences into account while avoiding the repetition of exclusion. Rather than set different work for a pupil with special support needs (Michael), and a student who may have been seen as needing 'accelerated' learning (Ben) she engaged them in a lesson that took account of their individual differences by making meaningful choices available to everyone. As we have learned from the pupils in our study, once a genuinely held belief in their competence is communicated both in word and deed, pupils will trust that teachers are listening and choose to engage and participate in 
activities that are genuine and meaningful to them as learners, thereby giving true meaning to the concept of inclusion.

\section{Acknowledgement}

This research was supported by a grant from the Esmée Fairbairn Foundation

\section{Reference list}

Allan, J. (2006) The repetition of exclusion. International Journal of Inclusive Education, $10,121-133$.

Beaton, M.C. (2015) Engaged Voices? An Exploration of the Development of Learner Identity. (Unpublished $\mathrm{PhD}$ thesis). University of Aberdeen, Aberdeen.

Black, P. \& Wiliam, D. (1998). Inside the black box Raising standards through classroom assessment. King's College, London

Black, P. \& William, D. (2009). Developing the theory of formative assessment. Educational Assessment Evaluation and Accountability, 21, 5-31.

Black-Hawkins, K. (2010) The Framework for Participation: A research tool for exploring the relationship between achievement and inclusion in schools, International Journal of Research Methods in Education, 33 (1), 21-40.

Boud, D. (1995). Enhancing learning through self-assessment. London: Kogan Page.

Bourke, R. (2016). Liberating the learner through self-assessment. Cambridge Journal of Education, 46(1), 97-111.

Bourke, R. (2017). Informal and fearless learning: A child's gaze on inclusive practices. Presentation at The Inclusive Education Summit, October 27-29, Adelaide, Australia.

Bourke, R. \& Mentis, M. (2014). 'Self-assessment as a lens for learning'. This is a chapter. In L. Florian (Ed.), The SAGE handbook of special education. (pp.537-552) London: SAGE.

Brookhart, S. M., Andolina, M., Zuza, M. and Furman, R., (2004). Minute Math: An Action Research Study of Student Self-Assessment. Educational Studies in Mathematics, 57, 213-227.

Brown, S. \& McIntyre, D. (1992). Making Sense of Teaching. Buckingham: Open University Press.

Coyle, D. (2011). Italic Research Report Investigating Student Gains: Content and Language Integrated Learning. Aberdeen: University of Aberdeen.

Coyle, D., Hood, P., \& Marsh, D. (2010) CLIC content and language integrated learning pp 69-72. Cambridge: Cambridge University Press 
English, A. (2011). Critical listening and he dialogic aspect of moral education: J.F. Herbart's concept of the teacher as a moral guide. Educational Theory, 61, 171-189. doi:10.1111/j.1741-5446.2011.00398.x

Falchikov, N. (2005). Improving assessment through student involvement: practical solutions for aiding learning in higher and further education. London: RoutledgeFalmer.

Florian, L., Black-Hawkins, K., \& Rouse, M. (2017) Achievement and Inclusion in Schools, $2^{\text {nd }}$ edition, London: Routledge.

Florian, L. (2015) 'Conceptualising inclusive pedagogy: The inclusive pedagogical approach in action'. This is a chapter. In J. Deppeler, T. Loreman, R. Smith, \& L. Florian (Eds.). Inclusive Pedagogy Across the Curriculum, International Perspectives on Inclusive Education, Volume 6. Melbourne: Emerald.

Florian. (2011) Exploring Inclusive Pedagogy. British Educational Research Journal, 37(5), 813-828. doi: 10.1080/01411926.2010.501096

Florian. \& Kershner, R. (2009) Inclusive Pedagogy. In H. Daniels, H. Lauder and J. Porter (Eds.) Knowledge, Values and Educational Policy: A Critical Perspective, pp. 173183, London: Routledge.

Grumet, M.R. (2014). The question of teacher education. LEARNing Landscapes, 8, 1, 21-26. Retrieved from www.learninglandscapes.ca/images/documents/11no15/mrgrumet.pdf.

Gunter, H. \& Thomson, P. (2007). Learning about student voice. Support for Learning, 22, 4, 181-188.

Hargreaves, E. (2005). Assessment for Learning? Thinking outside the (black) box. Cambridge Journal of Education, 35, 2, 213-224.

Hargreaves, E. (2012). Teachers' classroom feedback: still trying to get it right. Pedagogies: An International Journal, 7(1), 1-15.

Hargreaves, E. (2013). Inquiring into children's experiences of teacher feedback: reconceptualising Assessment for Learning. Oxford Review of Education, 39(2), 229-246.

Hart, S., Dixon, A., Drummond, M.J. \& McIntyre, D. (2004). Learning Without Limits. Maidenhead, Berkshire: OUP.

Hayward, L., Priestley, M. \& Young, M. (2004). Ruffling the calm of the ocean floor: merging practice, policy and research in assessment in Scotland. Oxford Review of Education, 30, 3, 397-415.

Hintz, A., \& Tyson, K. (2015) Complex listening: Supporting students to listen as Mathematical sense-makers. Mathematical Thinking and Learning, 17(4), 296-326.

Malaguzzi, L. (1994). Your image of the child: Where teaching begins. Early Childhood Educational Exchange, 96, 52-61

McIntyre, D. (2009) The difficulties of inclusive pedagogy for initial teacher education and some thoughts on the way forward. Teaching and Teacher Education, 25, 4, 602-608. 
Pryor, J. \& Crossouard, B. (2008). A socio-cultural theorisation of formative assessment. Oxford Review of Education, 34, 1, 1-20.

Pryor, J., \& Crossouard, B. (2010). Challenging formative assessment: disciplinary spaces and identities. Assessment and Evaluation in Higher Education, 35, 3, 265-276.

Rinaldi, C. (2001) A pedagogy of listening. Children in Europe, 1, 2-5

Sadler, D.R. (1989). Formative assessment and the design of instructional systems. Instructional Science, 18, 119-144.

Slee, R. (2010). The irregular school: Exclusion, schooling and inclusive education. London: Routledge.

Spratt, J., \& Florian, L. (2015). From learning to action: supporting each individual in the context of 'everybody'. Teaching and Teacher Education, 49, 89-96. doi:10.1016/j.tate.2015.03.006

Whitelock, D., Faulkner, D. \& Miell, D. (2008). Promoting creativity in Ph.D supervision: Tensions and dilemmas. Thinking Skills and Creativity, 3, 2, 143-153. doi: 10.1016/j.tsc.2008.04.001 